\title{
Correction: Primary lateral sclerosis: consensus diagnostic criteria
}

Turner MR, Barohn RJ, Corcia P, et al. Primary lateral sclerosis: consensus diagnostic criteria. J Neurol Neurosurg Psychiatry 2020;91:373-7.

In this paper, Georg Haase should have been included in the collaborators list.

\section{(2) \\ OPEN ACCESS}

Open access This is an open access article distributed in accordance with the Creative Commons Attribution 4.0 Unported (CC BY 4.0) license, which permits others to copy, redistribute, remix, transform and build upon this work for any purpose, provided the original work is properly cited, a link to the licence is given, and indication of whether changes were made. See: https://creativecommons.org/licenses/by/4.0/.

(c) Author(s) (or their employer(s)) 2020. Re-use permitted under CC BY. Published by BMJ.

J Neurol Neurosurg Psychiatry 2020;91:e1. doi:10.1136/jnnp-2019-322541corr1

D) Check for updates 